\title{
ОСОБЛИВОСТІ БІОХІМІЧНИХ ТА ІМУНОЛОГІЧНИХ МАРКЕРІВ У ДІТЕЙ З КОРОВОЮ ІНФЕКЦІЕЮ ТА В АСОЦІАЦІЇ З ГЛИСТЯНОЮ ІНВАЗІЕЮ
}

\author{
Ужгородський національний університет
}

\begin{abstract}
Звертається увага на поширені хвороби дитячого віку - кір і глистяну інвазію. Було вивчено особливості біохімічних та імунологічних маркерів у дітей, хворих на кір та його асоціацію з глистяною інвазією, яка ускладнює перебіг кору.
\end{abstract}

Ключові слова: кір, глистяна інвазія, біохімічне дослідження, діmu.

Кір протягом багатьох десятиліть був однією 3 найбільш розповсюджених дитячих захворювань у світі [1] і на сучасному етапі залишається надзвичайно важливою проблемою для системи охорони здоров'я [2]. Це одне 3 найпоширеніших інфекційних захворювань, збудник якого постійно циркулює в людській популяції [3]. За даними ретроспективного аналізу, спалахи захворюваності на кір в Україні спостерігали в 2001 р. (16 970 випадків), у 2006 р. (42 724) та в 2012 р. (12 746 випадків) [2]. Актуальність теми кір підтверджується небезпечними ускладненнями цієї інфекції, зокрема частим виникненням пневмонії і можливим ураженням ЦНС з розвитком енцесраліту, виразково-некротичним ураженням слизових оболонок ротової порожнини та кишечнику, гнійним отитом [4]. $€$ багато наукових досліджень, присвячених вивченню клінічної картини кору, виникненню та перебігу захворювання, але мало робіт присвячено розгляду проблеми поєднання кору з іншими захворюваннями та впливу вірусу кору на перебіг інших хвороб.

Гельмінтози - найпоширеніші паразитарні захворювання людини, що виникають унаслідок складних взаємовідносин між високоорганізованими багатоклітинними паразитами та макроорганізмом [5, 6]. Згідно 3 даними офріційної статистики, в Україні реєструють 300-400 тис. випадків гельмінтозів щороку, із них $80 \%$ у дітей [7]. Актуальність проблеми зумовлена передусім значною поширеністю, вираженим негативним впливом на організм людини, поліморфізмом клінічних проявів, який утруднює диференційну діагностику захворювань, відсутністю стерильного імунітету та специфрічних методів профрілактики [7].
Мета дослідження - дослідити особливості біохімічних та імунологічних маркерів у дітей 3 коровою інфекцією в асоціації з глистяною інвазією.

\section{Пацієнти і методи}

Для вивчення особливостей перебігу корової інсекції в асоціації з глистяною інвазією було проведено порівняльний аналіз історій 130 дітей віком від 1 до 4 років, які знаходились на стаціонарному лікуванні в обласній клінічній інфекційній лікарні м. Ужгорода з 2011 по 2012 рр., 3 основним діагнозом кір та супутнім діагнозом - глистяна інвазія (аскаридоз і трихоцефальоз). Обстежуваних дітей було поділено на дві групи: перша ( $n=87$ пацієнтів) - 3 основним діагнозом кір та супутнім діагнозом - глистяна інвазія; друга ( $n=43)$ - 3 основним діагнозом кір. Дані обстежень порівнювались 3 даними 25 практично здорових дітей, мешканців Закарпатської області.

\section{Результати досліджень та їх обговорення}

Вивчено біохімічні тести, мікроелементи, а також рівні цитокінів та імуноглобулінів.

Дані біохімічного обстеження венозної крові обох груп дітей представлені в таблиці 1.

При порівнянні біохімічного аналізу крові у дітей 3 коровою інфекцією та асоційованою глистяною інвазією можна відзначити такі відмінності. У групі дітей 3 асоційованою патологією були вищими показники АлАТ $(44,50 \pm 8,21)$ од./л та був зниженим показник рівня загального білка $(60,33 \pm 1,60)$ г/л. В обох групах мали тенденцію до підвищення показники АсАТ - $(64,92 \pm 2,83)$ та $(64,29 \pm 2,10)$ од./л відповідно по групах та рівні тимолової проби $(5,21 \pm 0,29)$ та $(5,12 \pm 0,11)$ од.

Констатуючи той фракт, що були підвищені рівні АлАТ, АсАТ та показники тимолової проби, особливо у дітей 3 асоційованою глистяною інвазією, можна зробити висновок про виражену запальну реакцію організму, вірусний та паразитарний токсичний вплив на гепатоцити з порушенням фрункції печінки. 
ОРИГІНАЛЬНІ ДОСЛІДЖЕННЯ

Таблиця 1

Біохімічний аналіз обстежуваних груп дітей, $\mathrm{M} \pm m$

\begin{tabular}{|l|c|c|c|}
\hline \multicolumn{1}{|c|}{ Показник } & 1-а група $(\mathrm{n}=52)$ & 2-а група $(\mathrm{n}=21)$ & $\mathrm{p}$ \\
\hline Білірубін загальний (до 17,10 мкмоль/л) & $6,52 \pm 0,62$ & $5,86 \pm 0,35$ & $>0,05$ \\
\hline Білірубін прямий (до 5 мкмоль/л) & $3,05 \pm 0,49$ & $2,27 \pm 0,31$ & $>0,05$ \\
\hline Білок загальний (66-83 г/л) & $60,33 \pm 1,60$ & $63,10 \pm 0,84$ & $>0,05$ \\
\hline Альбумін (35-50 г/л) & $41,92 \pm 1,09$ & $42,14 \pm 0,66$ & $>0,05$ \\
\hline АлАТ (до 40 Од/л) & $44,50 \pm 8,21$ & $33,24 \pm 2,17$ & $>0,05$ \\
\hline АсАТ (до 38 Од/л) & $64,92 \pm 2,83$ & $64,29 \pm 2,10$ & $>0,05$ \\
\hline АсАТ/АлАТ & 1,8 & 1,9 & $>0,05$ \\
\hline ГГТ (7-50 Од/л) & $48,72 \pm 1,41$ & $20,05 \pm 2,98$ & $<0,001$ \\
\hline Креатинін (53-123,7 мкмоль/л) & $53,16 \pm 2,97$ & $46,4 \pm 1,76$ & $<0,001$ \\
\hline Сечовина (2,49-7,49 ммоль/л) & $3,70 \pm 0,28$ & $2,81 \pm 0,62$ & $>0,05$ \\
\hline Лужна фроссратаза (до 700 Од/л) & $262,94 \pm 21,03$ & $342,52 \pm 27,39$ & $<0,05$ \\
\hline Тимолова проба (до 5 Од) & $5,21 \pm 0,29$ & $5,12 \pm 0,11$ & $>0,05$ \\
\hline Альра-амілаза (12-32 г/год×л) & $18,97 \pm 1,98$ & $16,76 \pm 1,47$ & $>0,05$ \\
\hline Глюкоза (3,33-6,11 ммоль/л) & $5,42 \pm 0,19$ & $5,11 \pm 0,47$ & $>0,05$ \\
\hline
\end{tabular}

Примітка. $p$ - вірогідна відмінність $(p<0,05)$ між даними біохімічних показників крові у хворих першої та другої груп.

Нами було проведено порівняльний аналіз рівнів $\lg$, IgM, IgE та IgA між групами обстежуваних дітей, які визначали при поступленні хворих до стаціонару (табл. 2).

Таблиця 2

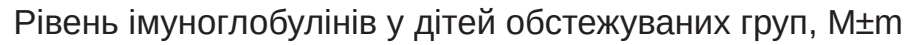

\begin{tabular}{|c|c|c|c|c|}
\hline Показник & Здорові діти (n=25) & 1-а група $(n=40)$ & 2-a група (n=20) & $\mathrm{p}$ \\
\hline $\lg E$ & $21,26 \pm 21,24$ & $322,59 \pm 47,57$ & $68,52 \pm 9,36$ & $\begin{array}{c}\mathrm{p}_{, 2}<0,001 \\
\mathrm{p}_{1,3}<0,001 \\
\mathrm{p}_{2,3}<0,05\end{array}$ \\
\hline $\lg G$ & $9,95 \pm 0,20$ & $17,89 \pm 0,88$ & $15,93 \pm 0,76$ & $\begin{array}{l}\mathrm{p}_{1,2}>0,05 \\
\mathrm{p}_{1,3}<0,001 \\
\mathrm{p}_{2,3}<0,001\end{array}$ \\
\hline $\lg M$ & $1,48 \pm 0,42$ & $3,67 \pm 0,16$ & $2,70 \pm 0,12$ & $\begin{array}{c}\mathrm{p}_{1,2}<0,001 \\
\mathrm{p}_{1,3}<0,001 \\
\mathrm{p}_{2,3}<0,01\end{array}$ \\
\hline $\lg A$ & $0,98 \pm 0,11$ & $1,88 \pm 0,16$ & $1,16 \pm 0,21$ & $\begin{array}{c}\mathrm{p}_{1,2}<0,01 \\
\mathrm{p}_{1,3}<0,001 \\
\mathrm{p}_{2,3}>0,05\end{array}$ \\
\hline
\end{tabular}

Примітки: $p_{1,3}$ - вірогідна відмінність $(p<0,05)$ між даними рівнів імуноглобулінів у здорових дітей та хворих першої групи; $\mathrm{p}_{2,3}$ - у здорових та хворих другої групи; $\mathrm{p}_{1,2}-$ у хворих першої та другої групи.

За нашими даними, спостерігалося різке підвищення рівня IgЕ у 1-ій групі $(322,59 \pm 47,57)$ проти $(68,52 \pm 9,36)$ у 2-ій групі та $(21,26 \pm 21,24)$ од./мл у групі здорових дітей, $\left.\mathrm{p}_{1,2}<0,001, \mathrm{p}_{1,3}<0,001, \mathrm{p}_{2,3}<0,01\right)$. При визначенні рівнів IgM, які зазвичай визначають в ранній період захворювання у сироватці крові, ми спостерігали також переважаюче підвищення даної категорії імуноглобулінів у першій групі $(3,67 \pm 0,16)$ та $(2,70 \pm 0,12)$ проти
$(1,48 \pm 0,42)$ мг/мл, $\left.\mathrm{p}_{1,2}<0,001, \mathrm{p}_{1,3}<0,001, \mathrm{P}_{2,3}<0,01\right)$. Результати дослідження рівнів IgG не є високими, так як вони починають синтезуватися після періоду переважання IgM і складають такі значення $(17,89 \pm 0,88)$ та $(15,93 \pm 0,76)$ відповідно по групах проти $(9,95 \pm 0,20)$ мг/мл групи здорових дітей, $\left.\mathrm{p}_{1,3}<0,001, \mathrm{p}_{2,3}<0,001\right)$. Рівні IgA, за нашими даними, варіювали в межах референтних величин, хоча достовірно перевищували в першій групі проти 
даних другої та групи здорових дітей: $(1,88 \pm 0,16)$ проти $(1,16 \pm 0,21)$ та $(0,98 \pm 0,11)$ г/л, $\left.p_{1,2}<0,01, p_{1,3}<0,001\right)$.
Важливе значення в патогенезі інфекційних захворювань надається порушенню балансу цитокінів (табл. 3).

Таблиця 3

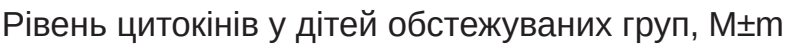

\begin{tabular}{|c|c|c|c|c|}
\hline Показник & Здорові діти (n=25) & 1-a група $(n=40)$ & 2-a група (n=22) & $\mathrm{p}$ \\
\hline IL-1 & $0,64 \pm 0,05$ & $0,80 \pm 0,06$ & $1,12 \pm 0,18$ & $\begin{array}{l}\mathrm{p}_{1,3}<0,05 \\
\mathrm{p}_{2,3}<0,01 \\
\mathrm{p}_{1,2}>0,05\end{array}$ \\
\hline IL-2 & $2,31 \pm 0,03$ & $12,73 \pm 2,0$ & $12,21 \pm 3,31$ & $\begin{array}{c}\mathrm{p}_{1,3}<0,001 \\
\mathrm{p}_{2,3}<0,001 \\
\mathrm{p}_{1,2}>0,05\end{array}$ \\
\hline IL-6 & $1,19 \pm 0,15$ & $30,01 \pm 1,96$ & $15,66 \pm 1,50$ & $\begin{array}{l}\mathrm{p}_{1,3}<0,001 \\
\mathrm{p}_{2,3}<0,001 \\
\mathrm{p}_{1,2}<0,001\end{array}$ \\
\hline IL-10 & $9,41 \pm 1,64$ & $16,65 \pm 0,67$ & $20,19 \pm 3,61$ & $\begin{array}{c}\mathrm{p}_{1,2}>0,05 \\
\mathrm{p}_{1,3}<0,001 \\
\mathrm{p}_{2,3}<0,01\end{array}$ \\
\hline
\end{tabular}

Примітки: $p_{13}$ - вірогідна відмінність ( $\left.<<0,05\right)$ між даними імунограми у здорових дітей і хворих першої групи; $p_{23}-y$ хворих другої групи; $p_{1,2}-$ у хворих першої та другої груп.

Під впливом високого рівня IgЕ активується медіатор запалення IL-1, але, за нашими дослідженнями, відбувалася незначна індукція синтезу даного інтерлейкіну $(0,80 \pm 0,06)$ та $(1,12 \pm 0,18)$ відповідно по групах проти $(0,64 \pm 0,05)$ пг/мл $\left(p_{1,3}<0,05, p_{2,3}<0,01\right)$, що підтверджує вплив глистяної інвазії на зниження захисної реакції в плані противірусної активності. Рівні IL-2 достовірно збільшені в обох групах $(12,73 \pm 2,0)$ у 1-ій групі та $(12,21 \pm 3,31)$ пг/мл по відношенню до групи здорових дітей $(2,31 \pm 0,03)$ пг/мл $\left(p_{1,3}<0,001, p_{2,3}<0,001\right)$ і переважання складає біля 6 разів.
Спостерігалося різке підвищення значень IL-6 $(30,01 \pm 1,96)$ та $(15,66 \pm 1,50)$ пг/мл проти даних групи здорових дітей $(1,19 \pm 0,15)$ пг/мл $\left(\mathrm{p}_{1,3}<0,001, \mathrm{p}_{2,3}<0,001\right)$. Високими були показники й IL-10, що з достовірністю відрізнялися в обох групах порівняно з групою здорових дітей $(16,65 \pm 0,67)$ у 1-ій групі та $(20,19 \pm 3,61)$ пг/мл у 2-ій групі проти $(9,41 \pm 1,64)$ пг/мл у групі здорових дітей $\left(p_{1,3}<0,001, p_{2,3}<0,01\right)$.

Нами досліджувався мікроелементний склад крові у дітей по групах (табл. 4).

Таблиця 4

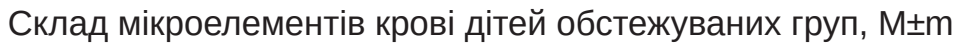

\begin{tabular}{|l|c|c|c|}
\hline \multicolumn{1}{|c|}{ Показник } & 1-а група $(\mathrm{n}=40)$ & 2 -а група $(\mathrm{n}=32)$ & $\mathrm{p}$ \\
\hline Залізо (8,9-22,5 мкмоль/л) & $20,17 \pm 1,97$ & $25,02 \pm 4,24$ & $>0,05$ \\
\hline Мідь (0,75-1,3 мг/л) & $0,21 \pm 0,01$ & $0,68 \pm 0,06$ & $<0,001$ \\
\hline Цинк (0,65-1,4 мг/л) & $0,42 \pm 0,01$ & $0,55 \pm 0,04$ & $<0,001$ \\
\hline Фосфрор (387-750 ммоль/л) & $825,0 \pm 20,1$ & $632,5 \pm 61,4$ & $<0,01$ \\
\hline Йод (80-120 нг/л) & $49,40 \pm 0,38$ & $69,40 \pm 0,36$ & $<0,001$ \\
\hline
\end{tabular}

Примітка. $\mathrm{p}$ - вірогідна відмінність $(\mathrm{p}<0,05)$ між даними мікроелементного складу крові у обстежуваних хворих.

За даними дослідження, з високим ступенем достовірності між групами були нижчими цифрові значення вмісту йоду в обох групах - $(49,40 \pm 0,38)$ проти $(69,40 \pm 0,36)$ нг/л відповідно по групах - p<0,001), міді - $(0,21 \pm 0,01)$ у 1 -ій групі та $(0,68 \pm 0,06)$ мг/л у 2-ій групі $(p<0,001)$ та цинку - $(0,42 \pm 0,01)$ та $(0,55 \pm 0,04)$ мг/л від- повідно по групах, p<0,001). Значення фросфрору були достовірно вищими у 1-ій групі проти 2-ої - $(825,0 \pm 20,1)$ проти $(632,50 \pm 61,42)$ ммоль/л, р<0,01.

Отже, показовими є зниження рівнів міді, цинку, йоду та підвищення рівня фросфору, особливо у групі 3 асоційованою глистяною інвазією. 
Золотим стандартом порушень мікроелементного обміну $€$ аналіз елімінації мікроелементів із сечею (табл. 5).

За нашими даними, з високим ступенем достовірності між групами були нижчими цифрові значення вмісту заліза - $(0,23 \pm 0,02)$ проти $(0,42 \pm 0,05)$ мг/л, міді $(2,00 \pm 0,41)$ у 1 -ій групі по відношенню до $(3,78 \pm 0,34)$ мг/л другої групи. У групі з асоційованою глистяною інвазією рівні цинку були достовірно нижчими порівняно 3 групою дітей 3 кором - $(2,75 \pm 0,20)$ проти $(3,78 \pm 0,34)$ мг/л, а також достовірно вищими були показники фроссрору $(927,25 \pm 18,12)$ у 1-ій групі проти $(626,93 \pm 49,20)$ ммоль/л 2-ої групи, p<0,001. Тобто, спостерігався мікроелементний дисбаланс при коровій інорекції, що більше виражений у дітей з гельмінтозами, так як наявність паразитів спричиняє деоріцит мікроелементів.

Склад мікроелементів сечі дітей обстежуваних груп, $\mathrm{M} \pm \mathrm{m}$

\begin{tabular}{|l|c|c|c|}
\hline \multicolumn{1}{|c|}{ Показник } & 1-а група $(\mathrm{n}=40)$ & 2-а група $(\mathrm{n}=35)$ & $\mathrm{p}$ \\
\hline Залізо (0,6-1,6 мг/л) & $0,23 \pm 0,02$ & $0,42 \pm 0,05$ & $<0,001$ \\
\hline Мідь (3,36-5,0 мг/л) & $2,00 \pm 0,41$ & $3,78 \pm 0,34$ & $<0,001$ \\
\hline Цинк (3,5-5,9 мг/л) & $2,75 \pm 0,20$ & $3,74 \pm 0,38$ & $<0,05$ \\
\hline Фоссрор (100-700 ммоль/л) & $927,25 \pm 18,12$ & $626,93 \pm 49,20$ & $<0,001$ \\
\hline Йод (200-700 мг/л) & $220,00 \pm 14,7$ & $306,02 \pm 30,31$ & $<0,001$ \\
\hline
\end{tabular}

Примітка. $p$ - вірогідна відмінність $(p<0,05)$ між даними мікроелементного складу сечі в обстежуваних хворих.

Таким чином, за нашими даними, у дітей з гельмінтозами спостерігалося різке підвищення рівнів IgE та IgM. Показовими були значення показників IL-6, IL-2 та IL-10 в обох групах.

Показовими були зниження рівнів міді, цинку, йоду та підвищення рівня оросорору в крові, зниження рівнів заліза, міді, цинку та підвищення показників фоосфору у сечі, особливо у групі з асоційованою глистяною інвазією.

\section{Висновки}

1. Аналіз маркерів алергічно-запальної відповіді дітей, хворих на кір в асоціації з глистяною інвазією, в гострому періоді захворювання показав: підвищення показників АлАТ, АсАТ, тимолової проби, що свідчить про виражену запальну реакцію організму, вірусний та паразитарний токсичний вплив на гепатоцити з порушенням фрункції печінки. Спостерігалося різке підвищення рівнів IgE, IgM та значень IL-6.

2. В обстежуваних дітей при коровій інфекції в асоціації з глистяною інвазією виявлено в організмі дисбаланс мікроелементів: в крові показовими були зниження рівнів міді, цинку, йоду та підвищення рівня фросфору, при дослідженні мікроелементного складу сечі - низькі значення вмісту заліза, міді, цинку, а також підвищені показники фоссфору.

Отже, розвиток дисбалансу імунологічних показників, кількісні і функціональні зміни периферичної крові, порушення нормальних співвідношень клітинних субпопуляцій, що служить основою порушення імунологічної реактивності, свідчать про зниження резистентності організму і розвиток імунної недостатності при паразитарних інвазіях.

\section{Література}

1. Сучасні проблеми елімінації кору в Україні / [Л.М. Чудна, Г.В. Мойсеєва, Л.С. Красюк та ін.] // Інфекційні хвороби. - 2008. - №3. - С. 5-13.

2. Малий В.П. Сучасні проблеми кору: клінічна картина, діагностика та лікування / В.П. Малий // Клінічна імунологія. Алергологія. Інфектологія. - 2012. - № 1-2. - С. 10-17.

3. Возианова Ж.И. Инфекционные и паразитарные болезни : : учеб. пособие / Ж.И. Возианова: в 3 т. - К.: Здоров'я, 2001. T. 2. $-692 \mathrm{c}$.

4. Крамарєв С.О. Сучасний перебіг кору у дітей / С.О. Крамарєв, О.В. Виговська, І.В. Шпак // Дитячий лікар. - 2013. - № 3 (24). - C. $26-31$.

5. Вінницька О.В. Гельмінтози: діагностичний пошук та лікування / О.В. Вінницька // Клінічна імунологія. Алергологія. Інсректологія. - 2009. - № 4 (23). - С.33-39.

6. Сергиев В.П. Паразитарные болезни человека. / В.П. Сергиев, Ю.В. Лобзин, С.С. Козлов. - СПб, Фолиант, 2006. - С. 211-448, 361-364, 352- 361.

7. Астафьев Б.А. Достижения отечественной науки в изучении патогенеза гельминтозов / Б.А. Астасьев // Мед. паразитол. и паразитарные болезни. - 1998. - № 2. - С. 8-11.

\section{BIOCHEMICAL AND IMMUNOLOGICAL FEATURES IN MEASLES CHILDREN WITH HELMINTHIASIS ASSOCIATION}

M.A. Polyak

SUMMARY. This article presented to the extremely frequency of measles with helminthiasis in the children. We investigated the biochemical and immunological markers of Measles with helminthiasis in the children and complication of the dutarion of disease.

Key words: measles, helminthiasis, biochemical investigation, children.

Отримано 11.11.2015 р. 